\title{
Intensity Modulated Radiotherapy is a Well-Tolerated and Effective Treatment for the Long-Term Control of Intra-Abdominal and Retroperitoneal Oligometastatic Renal Cell Cancer
}

\author{
Isabella Maund ${ }^{1,2}$, Anna Bowzyk Al-Naeeb ${ }^{1}$, Sarah J. Welsh, Tim Eisen and Kate Fife* \\ Cambridge University Hospitals NHS Trust, Addenbrooke's Hospital, Cambridge, UK
}

\begin{abstract}
.
Background: The use of conventionally fractionated intensity modulated radiotherapy (IMRT) in the management of oligometastatic renal cell carcinoma (RCC) is currently poorly characterised in the literature.

Objective: To evaluate the safety and effectiveness of IMRT for intraabdominal and retroperitoneal RCC oligometastases. Methods: Retrospective analysis of 14 patients with oligometastatic RCC treated with IMRT with the aim of inducing longterm control. Indications for radiotherapy included bleeding abdominal mass ( 5 patients), solitary renal bed recurrence ( 5 patients) and isolated, asymptomatic pancreatic mass (4 patients). The prescribed radiotherapy dose was 50 Gray in 20 to 25 fractions. Patients were followed up long-term using regular cross-sectional imaging and clinical review to assess local and distant disease control and treatment related toxicity.

Results: At median follow up of 33.5 (6-68) months, 12 patients remain alive (86\%), of whom 11 (92\%) have no evidence of local recurrence. Six patients (43\%) developed further metastatic disease, of whom $4(67 \%)$ received systemic treatment. Median duration of local control was 33.5 months, and 1- and 3-year overall survival (OS) was $92.9 \%$ and $85.7 \%$ respectively. No treatment-related toxicities $\geq$ grade 3 and no long-term sequelae were observed.

Conclusions: IMRT to intra-abdominal and retroperitoneal metastasis in oligo-metastatic RCC can be delivered safely, provide durable responses and excellent longer-term survival if given to a sufficiently high dose over a conventionally fractionated course. Our study is the first to date with long-term follow up to evaluate the role of IMRT in such cases and has important implications for treatment of oligometastatic RCC.
\end{abstract}

Keywords: Radiotherapy, IMRT, oligometastatic, intra-abdominal, retroperitoneal, pancreatic, renal cell carcinoma

\footnotetext{
${ }^{1}$ These authors are joint first authors.

${ }^{2}$ Current Address: Southend University Hospital, Prittlewell Chase, Westcliff-on-Sea, SS0 0RY.

${ }^{*}$ Correspondence to: Dr. Kate Fife, Department of Oncology, Box 193, Addenbrooke's Hospital, Cambridge University
}

Hospitals NHS Trust, Hills Road, Cambridge, CB2 0QQ, UK. Tel.: +44 01223 216364; Fax: +44 01223 217094; E-mail: Kate.fife@addenbrookes.nhs.uk. 


\section{INTRODUCTION}

A subset of patients with renal cell carcinoma (RCC) develop oligometastatic disease, in which metastases develop in single or a small number of sites. Common sites include pancreas (up to $13 \%$ of patients with metastatic disease; although this may rise with improved detection with modern imaging protocols [1-3]), paraaortic nodes (up to $15 \%$ in high-risk patients [4]) as well as local recurrences in the renal bed (in 3\% of patients [5]). Management can be challenging but, if left in situ, oligometastases and recurrences can cause pain, invade the duodenum or small bowel, and even cause lifethreatening haemorrhage [6]. A number of surgical series demonstrate that an aggressive local treatment approach can result in durable responses and control the disease for many years, often avoiding the need for systemic therapy $[7,8]$. The literature with regards to the role of conventionally fractionated radiotherapy, which may be a suitable option for a wider subset of patients, is by comparison, sparse.

Patients with oligometastases or renal bed recurrences are often considered for surgery and studies involving metastasectomy demonstrate improved PFS and OS in appropriately selected patients, with 5-year survival rates between 45-88\% [1, 9, 10] (Table 3). However, there are no prospective randomised studies to date and most data comes from retrospective studies and are limited by small sample size and selection bias [8, 11-14]. A systematic review of pancreatic surgery in metastatic RCC showed overall survival rates were 80.6 and $72.6 \%$ respectively at 2 and 5 years, compared to 41 and 14\% respectively in patients who did not undergo resection [15a]. However, surgery is limited by resectability and operability, given the significant risk of major surgery including complications related to general anaesthesia, wound healing and the risks of bleeding and fistula formation $[1,5$, 14]. Grade 3 and 4 complications were reported in one study in $14.7 \%$ of patients after surgery for isolated local retroperitoneal recurrence after radical nephrectomy for RCC, including two patients who died postoperatively of multi-organ failure [5].

Less invasive options, such as radiofrequency ablation (RFA), have been used to treat primary tumours as well as liver and lung metastases [16, 17]. RFA can be a treatment option in patients who are not fit for surgery and offers good local control, however there are limits on size and location of the target [18].

Although RCC has conventionally been considered a relatively radio-resistant tumour, fractionated radiotherapy has been shown to be an effective palliative treatment in up to $50 \%$ of patients with metastatic RCC [19]. Evidence for stereotactic body radiotherapy (SBRT) for RCC oligometastases is expanding [20-22]; results have been promising in controlling intracranial metastases (2-year local control of $91.4 \%$ and OS of 85\%) [23] and SBRT to thoracic, soft tissue and abdominal metastases has also shown excellent local control rates of greater than 90\% [24-26] (Table 2). Improved results are observed if patients are offered treatment for small volume metastatic disease [27]. It is suggested that SBRT may play a role in both prolonging the disease-free survival in patients with low-volume metastatic disease and in delaying the need to change or initiate systemic treatment in patients who develop progression of a solitary or limited number of metastases (so called 'oligoprogression') [27]. Conventionally fractionated radiotherapy is an appropriate treatment for patients where there are concerns regarding treatment safety and tolerability of other more invasive treatment options. Although SBRT may be an option for some of these patients, it is not universally available. There is little evidence available in the literature as to whether conventionally fractionated radiotherapy given at sufficiently high doses is associated with achieving long-term control in RCC. We therefore report our institution's experience with IMRT to isolated pancreatic, paraaortic or renal bed masses in patients with RCC as proof of concept of the utility of this technique.

\section{MATERIALS AND METHODS}

A retrospective analysis of patients with metastatic RCC receiving IMRT to a prescribed dose of $\geq 50$ Gray equivalent dose at 2 Gray (EQD2) for intraabdominal metastasis was undertaken. We reviewed electronic records and radiotherapy notes of patients who underwent radiotherapy between 2006 and 2016 under the care of The Cambridge University Hospitals NHS Trust. Patients were followed up with clinical review and CT at 3-6 monthly intervals following radiotherapy. This study was registered as a service review by the audit department at Cambridge University Hospitals. 


\section{Statistical analysis}

Overall survival (OS) was defined from date of completion of IMRT until death or last follow up. Local control was scored as an event if any treated lesion grew by $\geq 20 \%$, based on the Response Evaluation Criteria In Solid Tumors (RECIST) Version 1.1 criteria or a local failure was confirmed pathologically. Graph Pad Prism version 7 was used for all data analysis.

\section{RESULTS}

Fourteen patients were identified. Patient characteristics, treatments and outcomes are shown in Table 1 . Median age at radiotherapy was 71 years (range 51-81). All patients had performance status 0 or 1 at the time of commencing radiotherapy. Prior to radiotherapy, 5 patients had received systemic treatment ( 2 patients- 2 lines, 3 patients- 1 line).

Indications for radiotherapy included bleeding abdominal mass (5 patients), renal bed recurrence (5 patients) and isolated, asymptomatic pancreatic mass (4 patients). Prescribed dose was 50 Gray in 20-25 fractions over 4-5 weeks. All patients were planned conformally using IMRT and tomotherapy techniques. Outlined organs at risk were: kidney, liver, small bowel and spinal cord. For a single kidney the dose constraint was V10Gy $<5 \%$ and mean dose $<5 \mathrm{~Gy}$; liver mean dose <25Gy; small bowel objective $<150 \mathrm{cc}>40 \mathrm{~Gy}$ and constraint V50 $<5 \%$; spinal cord constraint V40Gy<0\%.

All but one patient completed treatment as planned, and no grade 3 or 4 toxicity was observed. The commonest toxicity documented was nausea and lethargy (grade 1 or 2). One patient declined further treatment after 17 fractions (grade 2 lethargy). At first post radiotherapy imaging, 85.7\% (12) of patients had stable disease(SD) by RECIST. Of these, one patient $(7.1 \%)$ showed an additional finding of necrosis within the irradiated metastasis suggesting treatment response. He remains alive with no radiologically confirmed evidence of local progression at 50 months. Partial response(PR) was documented in $7.1 \%$ (1) of patients (he remains well with stable disease at 31 months). Although progressive disease (PD) was confirmed in $7.1 \%$ (1) on initial imaging, patient gained the palliative benefit in form of haemostasis. There were no long-term sequelae of radiotherapy observed during study period.

Overall survival at 1 and 3-years was $92.9 \%$ and $85.7 \%$ respectively, with median follow up of 33.5 months (Fig. 1A). Median duration of local control was 33.5 months (range 6-68) (Fig. 1B). Twelve patients remain alive $(85.7 \%)$, of whom $11(92 \%)$ have no evidence of local recurrence. Six out of the original 14 patients (43\%) developed metastatic disease, 4 of whose irradiated site remains stable. Four of these 6 patients $(67 \%)$ have received systemic treatment ( 3 of whom received a tyrosine kinase inhibitor (TKI) and 1 patient received everolimus). Two patients (29\%) received RFA for isolated relapses outside the radiotherapy field (1 of whom later went on to require TKI therapy for multiple metastases). The remaining 8 of the original 14 patients $(57 \%)$ continue to have stable disease with no evidence of local or distant recurrence.

Over the study period, two patients (14.2\%) relapsed at the irradiated site ( 3 and 35 months after completing radiotherapy). The patient who relapsed after 3 months did not complete the prescribed course of radiotherapy, receiving only 40.7 Gray in 17 fractions, as described above. The patient also developed distant metastases and died 6 months after completing radiotherapy. The other patient who relapsed locally developed very slow progression after 35 months and only started systemic therapy (with sunitinib) 14 months later after developing symptomatic liver metastases.

\section{DISCUSSION}

Conventionally fractionated IMRT for intraabdominal oligometastatic RCC was found to be safe, well tolerated, and associated with excellent long term control in our patient cohort. This study confirms the results from previous studies showing that an aggressive approach can result in durable responses and control the disease for a number of years [7, 8]. The overall survival rates in our study of $92.9 \%$ and $85.7 \%$ at 1 - and 3-years respectively, are comparable to reported overall survival rates of 80.6 and $72.6 \%$ at 2- and 5-years, respectively, for patients who underwent resection of pancreatic oligometasases and substantially better than the 2- and 5-year overall survival rates of 41 and $14 \%$ respectively in patients who did not undergo resection, in the same review [28]. Patients receiving surgery for oligometastatic disease are often highly selected in terms of performance status, co-morbidity and invasiveness of disease, whereas such requirements are less stringent for radiotherapy [14]. 
Table 1

Patient characteristics, treatment and outcome

\begin{tabular}{|c|c|c|c|c|c|c|c|c|c|c|c|c|c|c|}
\hline $\begin{array}{l}\text { Current } \\
\text { status }\end{array}$ & $\mathrm{FU}[\mathrm{m}]$ & $\begin{array}{l}\text { Time to } \\
\text { DP }[\mathrm{m}]\end{array}$ & $\begin{array}{l}\text { Time to } \\
\text { LP [m] }\end{array}$ & $\begin{array}{l}\text { Radiological } \\
\text { response }\end{array}$ & $\begin{array}{l}\text { Clinical } \\
\text { response }\end{array}$ & $\begin{array}{l}\text { Dose }[\mathrm{Gy}] / \\
\text { fractionation } \\
\text { Fractionation }\end{array}$ & $\begin{array}{l}\text { Site of } \\
\text { RT }\end{array}$ & $\begin{array}{l}\text { Date RT } \\
\text { completed }\end{array}$ & $\begin{array}{l}\text { Treated } \\
\text { tumour } \\
\text { size }[\mathrm{cm}]\end{array}$ & $\begin{array}{l}\text { Interval* } \\
{[\mathrm{m}]}\end{array}$ & $\begin{array}{l}\text { Number of } \\
\text { metastatic } \\
\text { sites }\end{array}$ & $\begin{array}{l}\text { Management } \\
\text { of primary, } \\
\text { and prior } \\
\text { therapy }\end{array}$ & Histology & $\begin{array}{l}\text { Year primary } \\
\text { diagnosed }\end{array}$ \\
\hline A, DP & 66 & 46 & NR & SD & NA & $50 / 20$ & $\mathrm{P}$ & $30 / 6 / 11$ & $5.2 ; 2.5$ & 2 & 1 & $\mathrm{RN}$ & Clear Cell & 2007 \\
\hline $\mathrm{A}, \mathrm{DP}$ & 50 & 38 & NR & $\mathrm{SD}, \mathrm{N}$ & NA & $50 / 25$ & $\mathrm{P}$ & $31 / 1 / 13$ & $\mathrm{U}$ & 10 & 4 & RN & Clear Cell & 2002 \\
\hline $\mathrm{A}, \mathrm{S}$ & 27 & NR & NR & SD & NA & $48 / 24$ & $\mathrm{P}$ & $12 / 12 / 14$ & 6.2 & 3 & 1 & PN & Clear Cell & 2011 \\
\hline A, S & 6 & NR & NR & SD & NA & $50 / 20$ & $\mathrm{P}$ & $13 / 07 / 16$ & U & 1 & 3 & RN & Clear Cell & 2014 \\
\hline $\mathrm{A}, \mathrm{PD}$ & 51 & 35 & 35 & SD & $\mathrm{CR}$ & $50 / 20$ & PA & $08 / 11 / 12$ & 2 & 1 & 3 & RN Sorafenib & Clear Cell & 2005 \\
\hline $\mathrm{A}, \mathrm{S}$ & 60 & NR & NR & SD & $\mathrm{CR}^{* *}$ & $50 / 20$ & PA & 09/12/11 & $\mathrm{U}$ & 5 & 1 & $\mathrm{RN}$ & Clear Cell & 2004 \\
\hline A, S & 31 & NR & NR & SD & NA & $50 / 25$ & PA & $21 / 03 / 14$ & 1.6 & 84 & 3 & $\begin{array}{l}\text { RN } \\
\text { Regorafenib }\end{array}$ & Clear Cell & 2006 \\
\hline D & 68 & 58 & NR & SD & $\mathrm{CR}$ & $50 / 20$ & PA & 07/05/10 & 7.8 & 6 & 1 & RN, Sunitinib & Papillary & 2007 \\
\hline D & 6 & 3 & 3 & PD & $\mathrm{CR}(\mathrm{H})$ & $40.7 / 17$ & A & $15 / 06 / 06$ & $\mathrm{U}$ & 3 & 3 & $\mathrm{RN}$ & Clear Cell & 2002 \\
\hline A, S & 56 & NR & NR & SD & $\mathrm{CR}$ & $50 / 20$ & $\mathrm{RB}$ & 29/05/12 & 3.2 & 5 & 1 & $\begin{array}{l}\mathrm{RN} \text {, failed } \\
\text { resection } \\
\text { recurrence }\end{array}$ & Papillary & 2008 \\
\hline A, S & 22 & NR & NR & SD & CR & $50 / 25$ & RB & 11/11/14 & 1.8 & 2 & 1 & RN, Sorafenib, & Clear Cell & 2011 \\
\hline A, S & 8 & NR & NR & SD & CR & $50 / 25$ & $\mathrm{RB}$ & 16/03/16 & 3.5 & 48 & 1 & RN, & Clear Cell & 2005 \\
\hline A, DP & 34 & 31 & NR & SD & $\mathrm{CR}$ & $50 / 20$ & $\mathrm{RB}$ & $01 / 04 / 14$ & 2 & 2 & 1 & $\mathrm{RN}$ & Chromophobe & 2008 \\
\hline A, S & 33 & NR & NR & SD & CR & $50 / 20$ & RB & 09/05/14 & 4.5 & 2 & 1 & RN & Clear Cell & 2007 \\
\hline
\end{tabular}

*M-months; NR-Not reached; NA-not applicable; U-data unavailable; RT- Radiotherapy; SD-Stable disease; PR-partial response; PD-progressive disease; N-necrosis; H-haemostasis; P-pancreatic mass; RB-renal bed; PA-paraaortic mass; A-intra-abdominal mass, not otherwise specified; met-metastases; D-died; A-alive; DP-distant progression; S-Stable. *Interval between onset of metastases and radiotherapy; fract-fractionation; LP-local progression; RN-radical nephrectomy; PN-partial nephrectomy; CR-clinical response. **-recurrent small bowel obstruction due to paraaortic mass, less frequent following radiotherapy. 
Table 2

Published data related to conventional RT/SBRT in extracranial oligometastatic renal cell carcinoma ${ }^{1}$

\begin{tabular}{|c|c|c|c|c|c|c|c|c|}
\hline Author & Year & $\begin{array}{l}\text { Number } \\
\text { pts/mets }\end{array}$ & RT dose/\# & Site of RT & Systemic therapy & outcome & Median follow up & Toxicity \\
\hline $\begin{array}{l}\text { Altoos } \\
{[24]}\end{array}$ & 2015 & $34 / 53$ & $\begin{array}{l}\text { 50Gy/5\#(SBRT)- } \\
\text { 36/53lesions } \\
\text { 20Gy/ 5\#,30Gy/ } \\
\text { 10\#,40Gy/ } \\
\text { 10\#(CEBRT)- } \\
\text { 17/53lesions }\end{array}$ & $\begin{array}{l}\text { Lung/ skin/ soft } \\
\text { tis- } \\
\text { sue/abdominal }\end{array}$ & $\begin{array}{r}72 \% \text { before RT; } \\
57 \% \text { after RT }\end{array}$ & $\begin{array}{l}\text { SBRT-2\&3 years } \\
\text { LC:93.4\%; } \\
\text { CEBRT-2\&3 } \\
\text { years LC } \\
35 \%(p<0.001)\end{array}$ & 16 months & No grade $4 / 5$ \\
\hline $\begin{array}{l}\text { DiBiase } \\
{[42]}\end{array}$ & 1997 & $107 / 150$ & Various & $\begin{array}{l}\text { Bone/ Brain/ soft } \\
\text { tissue/ spinal } \\
\text { cord/lung }\end{array}$ & NS & $\begin{array}{l}\text { Median duration } \\
\text { palliation } 6 \\
\text { months (range } \\
\text { 1-150). } \\
\text { Increased RR } \\
\text { seen associated } \\
\text { with higher } \\
\text { BED }\end{array}$ & NS & NS \\
\hline $\begin{array}{l}\text { Gravis } \\
{[26]}\end{array}$ & 2015 & $7 / 8$ & $\begin{array}{c}36 \mathrm{~Gy} / 12 \# 42 \mathrm{~Gy} / 6 \# \\
\text { and } 40 \mathrm{~Gy} / 5 \#\end{array}$ & $\begin{array}{l}\text { Mediastinal/ lung/ } \\
\text { LN/ bone/ } \\
\text { adrenal }\end{array}$ & $\begin{array}{l}\text { Yes (all before } \\
\text { RT) }\end{array}$ & $\begin{array}{c}\text { Median LC >24 } \\
\text { months, no } \\
\text { local PFS }\end{array}$ & 34 months & No grade \\
\hline $\begin{array}{l}\text { Hoerner- } \\
\text { Rieber } \\
{[43]}\end{array}$ & 2017 & $46 / 67$ & $\begin{array}{l}\text { Median } 20.8 \mathrm{~Gy} \text { at } \\
\text { isocenter (range, } \\
6.0-37.9 \mathrm{~Gy}) / \text { median } \\
3 \text { (range } 1-8 \text { ) }\end{array}$ & Lung & $\begin{array}{l}52.2 \% \text { before } \\
\text { SBRT }(n=35) ; \\
40.3 \% \text { after } \\
(n=27)\end{array}$ & $\begin{array}{l}\text { 1- and 3-year LC } \\
98.1 \% \text { and } \\
91.9 \% \\
\text { respectively }\end{array}$ & 28.3 months & $\begin{array}{l}8.6 \% \text { acute grade } \\
2 ; 6.5 \% \text { late } \\
\text { grade }>2\end{array}$ \\
\hline $\begin{array}{l}\text { Onufrey } \\
{[44]}\end{array}$ & 1985 & $125 / 125$ & 20-60Gy CEBRT & $\begin{array}{l}\text { Bone/Brain/soft } \\
\text { tissue/spinal } \\
\text { cord }\end{array}$ & NS & $\begin{array}{l}\text { RR (clinical) } \\
65 \% \text { for higher } \\
\text { doses versus } \\
25 \% \text { for lower }\end{array}$ & NS & NS \\
\hline $\begin{array}{l}\text { Ranck } \\
{[23]}\end{array}$ & 2013 & $18 / 39$ & $\begin{array}{l}\text { 3-fraction } \\
\text { dose-escalation } \\
\text { protocol ( } 8 \text { to } \\
\text { 14Gy/\#) or off } \\
\text { protocol with } 10 \# \\
(4-5 \mathrm{~Gy} / \#)\end{array}$ & $\begin{array}{l}\text { Bone/ abdominal } \\
\text { LN/lung/ } \\
\text { mediastinum/ } \\
\text { adrenal/ } \\
\text { liver/soft } \\
\text { tissue/kidney }\end{array}$ & $\begin{array}{l}1 \text { year freedom } \\
\text { from post SBRT } \\
\text { therapy } 64.2 \%\end{array}$ & $\begin{array}{l}2 \text { years LC } \\
\quad \text { (estimated) } \\
91.4 \% ; \text { OS } \\
85 \% .\end{array}$ & 16.2 months & $\begin{array}{l}61.1 \% \text { acute } \\
\text { fatigue, low } \\
\text { rates late } \\
\text { toxicity }\end{array}$ \\
\hline $\begin{array}{l}\text { Svedman } \\
{[45]}\end{array}$ & 2006 & $30 / 82$ & $\begin{array}{l}\text { Various }(8 \mathrm{~Gy} \times 4,10 \\
\text { Gy } \times 4,15 \mathrm{~Gy} \times 2 \\
\text { or } 15 \mathrm{~Gy} \times 3)\end{array}$ & $\begin{array}{l}\text { Mediastinal/ lung/ } \\
\text { thoracic wall/ } \\
\text { adrenal/ } \\
\text { abdominal } \\
\text { glands/ } \\
\text { liver/spleen/pelvis }\end{array}$ & $\begin{array}{l}20 \% \text { prior to } \\
\quad \text { SBRT }(n=6) ; \\
30 \% \text { subsequent } \\
(n=9)\end{array}$ & LC $98 \%$ & $\begin{array}{l}52 \text { months }(22 \\
\text { months for } \\
\text { deceased } \\
\text { patients) }\end{array}$ & $\begin{array}{l}57 \% \text {. The majority } \\
(96 \%) \text { grade } \\
\text { I-II. One } \\
\text { possible grade } \\
5 .\end{array}$ \\
\hline
\end{tabular}


Table 2

(Continued)

\begin{tabular}{|c|c|c|c|c|c|c|c|c|}
\hline Author & Year & $\begin{array}{l}\text { Number } \\
\text { pts/mets }\end{array}$ & RT dose/\# & Site of RT & Systemic therapy & outcome & Median follow up & Toxicity \\
\hline $\begin{array}{l}\text { Wang } \\
\text { [46] }\end{array}$ & 2017 & $84 / 175$ & $\begin{array}{l}\text { 40-60Gy/5\#, } \\
\text { 30-54Gy/3\# } \\
20-40 \mathrm{~Gy} / 1 \#\end{array}$ & $\begin{array}{l}\text { Bone/thorax/ } \\
\text { abdomen/ } \\
\text { kidney/ soft } \\
\text { tissue/ spinal } \\
\text { cord }\end{array}$ & $52.6 \%$ prior SBRT & 1-year LC $91.2 \%$ & $\begin{array}{l}10.5 \text { months } \\
\quad \text { (lesions); } 16.7 \\
\text { months } \\
\text { (patients) }\end{array}$ & $\begin{array}{l}\text { Acute: } 10.4 \% \\
\text { grade } 1-2 ; 1.7 \% \\
\text { grade }>2 \text {. } \\
\text { Late: } 4.5 \% \text { all } \\
\text { grades } ; 2.9 \% \text { for } \\
\text { grade }>2\end{array}$ \\
\hline $\begin{array}{l}\text { Wersall } \\
\text { [25] }\end{array}$ & 2005 & $\begin{array}{l}58 / 50(8 \\
\text { patients } \\
\text { included with } \\
\text { primary } \\
\text { inoperable } \\
\text { disease })\end{array}$ & $\begin{array}{l}8 \text { Gyx } 4,10 \text { Gyx } 4 \text { and } \\
15 \text { Gyx } 3 \text { over } 1 \\
\text { week }\end{array}$ & $\begin{array}{l}\text { Various } \\
\text { extracranial } \\
\text { sites }\end{array}$ & NS & LC-90-98\% & 37 months & low \\
\hline $\begin{array}{l}\text { Zelefsky } \\
\text { [47] }\end{array}$ & 2012 & $55 / 105$ & $\begin{array}{l}24-30 \mathrm{~Gy} / 3-5 \# \\
\quad(43.8 \%) ; 18-24 / 1 \# \\
\quad(56.2 \%)\end{array}$ & $\begin{array}{l}\text { Spine/ pelvic } \\
\text { bones/ femur/ } \\
\text { other bone/LN }\end{array}$ & NS & $\begin{array}{l}\text { 3-year actuarial } \\
\text { local } \\
\text { progression- } \\
\text { free survival } \\
44 \% \\
\end{array}$ & 12 months & $\begin{array}{l}\text { Dermatitis: } 4 \% \\
\text { grade } 2,2 \% \\
\text { grade } 4 . \\
\text { Fracture } 7 \% \\
\text { patients } \\
\end{array}$ \\
\hline
\end{tabular}

'metastases'. 
Table 3

Example surgical series of patients with metastatic renal cell carcinoma treated by surgical resection of metastases

\begin{tabular}{|c|c|c|c|c|c|c|}
\hline Author & Year & $\begin{array}{l}\text { Number } \\
\text { patients }\end{array}$ & Surgery & Post op M\&M rate & Median follow up & Outcome \\
\hline Sohn [9] & 2001 & 10 & $\begin{array}{l}\text { Pancreatic } \\
\text { resection }\end{array}$ & NS & 15 months & 5-year survival $75 \%$ \\
\hline Faure [11] & 2001 & 8 & $\begin{array}{l}\text { Pancreatic } \\
\text { resection }\end{array}$ & none & 48 months & Mean survival 48 months \\
\hline Law [8] & 2003 & 14 & $\begin{array}{l}\text { Pancreatic } \\
\text { resection }\end{array}$ & 1 perioperative death & 32 months & $\begin{array}{l}50 \% \text { alive with no } \\
\text { recurrence } 28 \% \text { alive with } \\
\text { recurrence }\end{array}$ \\
\hline Akatsu [12] & 2007 & 4 & $\begin{array}{l}\text { Pancreatic } \\
\text { resection }\end{array}$ & NS & 39 months & Median survival 103 months \\
\hline Zerbi [1] & 2008 & 36 & $\begin{array}{l}\text { Pancreatic } \\
\text { resection }\end{array}$ & $\begin{array}{l}\text { No perioperative } \\
\text { mortality, the morbidity } \\
\text { rate }-47.8 \% \text {. }\end{array}$ & 31 & $\begin{array}{l}\text { 5-year actuarial survival rate } \\
\text { - } 88 \%, \text { median disease-free } \\
\text { survival }-44 \text { months. No } \\
\text { surgery :5-year survival } \\
\text { rate of } 47 \%, \text { median } \\
\text { survival time } 27 \text { months } \\
(P=0.02) .\end{array}$ \\
\hline D'Ambra [13] & 2011 & 7 & $\begin{array}{l}\text { Pancreatic } \\
\text { resection }\end{array}$ & $\begin{array}{l}\text { Morbidity- } 42.8 \%, \text { no } \\
\text { mortality }\end{array}$ & & $\begin{array}{l}\text { Median OS-43.0 months } \\
\quad \text { (range } 12.9-74.5), \text { med } \\
\text { DFS }-23.6 \text { months }\end{array}$ \\
\hline Grassi [40] & 2013 & 2 & $\begin{array}{l}\text { Pancreatic } \\
\text { resection }\end{array}$ & NS & 51 months & Median OS 39 months \\
\hline Markinez [14] & 2013 & 8 & $\begin{array}{l}\text { Pancreatic } \\
\text { resection }\end{array}$ & $\begin{array}{l}\text { 1- } \\
\text { haemorrhage/anastomosis } \\
\text { 1-pseudomembranous } \\
\text { colits+AKI+CS } 1 \text {-died } \\
\text { post op/torpid course }\end{array}$ & 30 months(mean) & $87.5 \%$ alive, $12.5 \%$ died \\
\hline Thomas [5] & 2015 & 102 & Retroperitoneal & $\begin{array}{l}14 \text { patients-grade } 3 \text { and } \\
\text { more }\end{array}$ & 32 months & $\begin{array}{l}\text { Median DFS and CSS after } \\
\text { RP resection was } 23 \\
\text { months and } 66 \text { months } \\
\text { respectively. One, } 3 \text { and } \\
5 \text {-year CSS was } 92 \%, 71 \% \\
\text { and } 52 \% \text {, respectively. }\end{array}$ \\
\hline
\end{tabular}

*M\&M-morbidity and mortality; med -median; OS-overall survival; DFS-disease free survival, CSS-cancer specific survival; ND-none documented; NS-nil significant; AKI-acute kidney injury; CS-compartment syndrome; RP-retroperitoneal.

Another important conclusion from our study was the absence of any grade 3 or 4 toxicities or long term sequalae from radiotherapy. Surgery for oligometastatic RCC is associated with significant toxicity (including death) which is an important consideration in this arguably palliative population group where $>40 \%$ are likely to develop other metastatic disease within 5 years [5]. In our study, although only 2 patients in our study relapsed within the radiotherapy field (including one patient who did not complete the full prescribed course of radiotherapy due to fatigue), $43 \%$ of patients developed further distant metastatic disease, of whom $67 \%$ received systemic therapy, within the follow up period. It is therefore important to consider the likelihood of long term toxicity when contemplating treatment of oligometastatic RCC in order to maintain fitness for future systemic treatments. Additionally, the excellent tolerability of radiotherapy allows treatment of patients who are relatively less fit, with co-morbidities, compared to surgery.

Radiofrequency ablation (RFA) is another treatment option for patients who are not considered suitable for surgery. RFA offers excellent rates of local control but the feasibility of treatment is limited by the size and location of the potential target [17]. Typically, lesions of up to $3 \mathrm{~cm}$ in size can be confidently treated with RFA provided there is a safe access (straight needle line, without bowel loops). Radiotherapy has the potential to treat much larger lesions and is less limited by location as long as radiotherapy dose constraints for the surrounding organs at risk can be met. Following RFA, a significant reduction in the size of the treated RCC metastases is frequently noted [18]. Radiotherapy, in contrast, frequently does not result in significant shrinkage of treated oligometastases, instead, stabilising the majority of treated oligometastases. Longer follow 

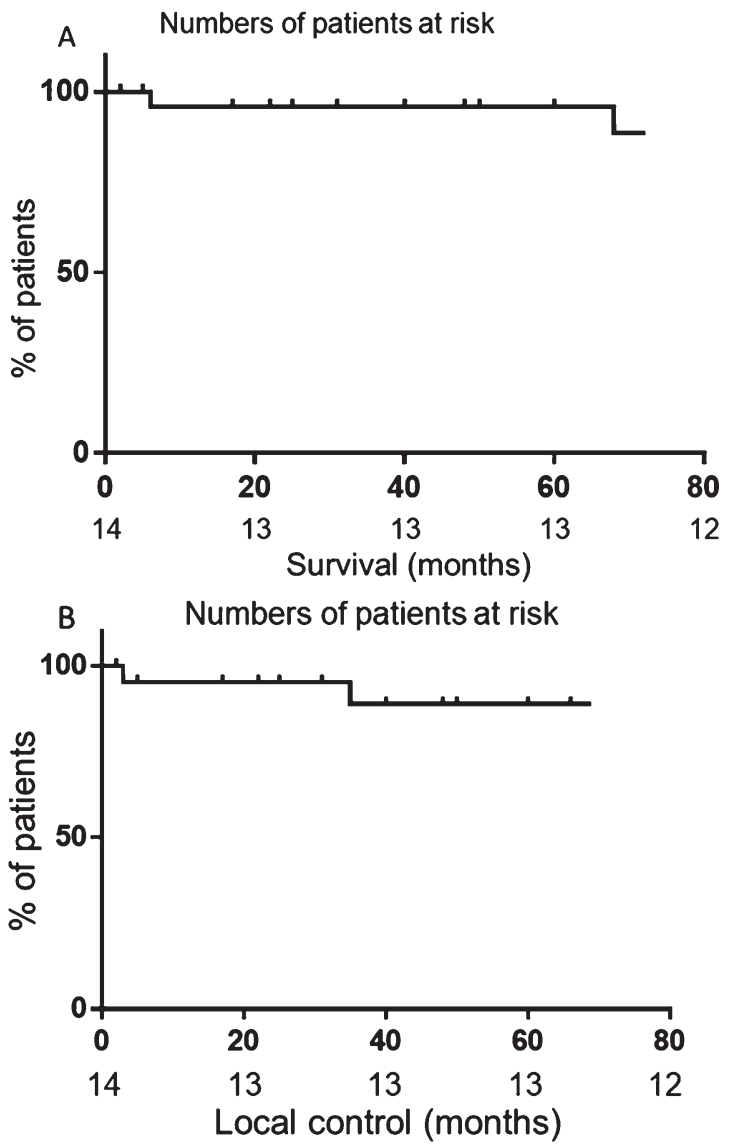

Fig. 1. Disease control after radiotherapy. A) Overall survival of patients treated with radiotherapy. B) Local control after treatment with radiotherapy. Censored subjects are noted by a dash on the graphs.

up is required to ascertain whether local recurrence may occur in the future and functional imaging may also be useful in confirming whether treated tumours remain metabolically active after radiotherapy.

The median local control rate of 33.5 months in the current study is comparable to the median local control rates at 24 and 36 months of $93 \%$ in patients treated with SBRT in a recent single institution study [24]. The same study reported significantly lower median local control rates of $35 \%$ at 24 and 36 months using conventional fractionated radiotherapy [24] although it should be noted that the radiotherapy doses used were considerably lower than those used in the present study. SBRT delivers higher doses (typically in excess of 8-10 Gy per fraction), in fewer fractions, than the conventional radiotherapy used in the current study. The biological rationale for delivery of ablative radiotherapy is to overcome the perceived inherent radio-resistance of RCC metastases. In vitro studies suggest that delivery of greater doses per fraction is associated with exponentially increased rates of cell death in RCC cell lines [29]. It is suggested this occurs as ablative doses activate alternate mechanisms of tumour cell death, for example tumour hypoxia secondary to endothelial damage, which are not seen at lower doses [30]. However, we know that in vitro observations do not always translate into clinically meaningful results. Furthermore, not all centres are able to offer SBRT due to the availability of equipment and staff trained in the advanced technical and quality assurance requirements mandated to deliver SBRT. The present study provides reassurance that conventionally fractionated radiotherapy, can also achieve excellent rates of control in oligometastatic $\mathrm{RCC}$, potentially enabling more patients to receive treatment at centres closer to home. We feel that the lack of access to SBRT should not be seen as a barrier to delivering higher doses of radiotherapy with the aim of durable local control.

Our results challenge the convention that RCC is a relatively radio-resistant tumour [31]. Some interesting work is emerging which may help us understand factors which contribute to the excellent local control rates achieved. Recent reports show that radiotherapy can change the direction of immunity against the tumour through increased intratumoural CD8+ $\mathrm{T}$ cell infiltration $[32,33]$. High dose radiation transformed the immunosuppressive tumour microenvironment resulting in an intense $\mathrm{CD} 8+\mathrm{T}$ cell tumour infiltrate, and a loss of myeloid derived suppressor cells, leading to durable responses in mouse models [34]. Additionally, in vitro models have shown that hypofractionated radiation induces 'immunotoxicity' in tumour, but not in healthy cells, leading to immune-mediated tumour destruction via activation of immature dendritic cells (DC) which stimulate CD4+ T-cells not only in an allogenic, but also in an antigen-specific manner [32]. Radiotherapy may also change the tumour microenvironment by releasing cytokines which increase its responsiveness to local radiotherapy increasing the likelihood of further systemic responses via the 'abscopal' effect [34-36]. Indeed, a prospective clinical trial of SBRT for inoperable primary RCC has demonstrated freedom from local progression, distant progression and overall survival at 2 years of $100 \%, 89 \%$ and $92 \%$, respectively [37], with baseline neutrophil to lymphocyte ratio being predictive of immune-mediated response offering a potential future biomarker of response to radiotherapy, though this needs further investigation. 
The possibility that radiotherapy augments immune responses and that the combination of radiotherapy and immunotherapy may lead to more durable local and systemic control is another concept which has sparked some excitement in the literature and, interestingly, TKIs (standard first line treatment of metastatic RCC) have also been shown to augment immune responses via vascular endothelial growth factor- (VEGF-) mediated effects on neutrophil migration, T lymphocyte-DC cross-talk, DC maturation and immune cell metabolism and reactivity [38]. Many questions remain unanswered regarding combinations of radiotherapy and immune- and TKI- directed therapies, including the optimal dose and fractionation, which agents should be used or how to provoke the optimal immune effect following irradiation of particular metastatic sites [36]. Eleven clinical trials investigating combinations of radiotherapy with systemic immune and TKI-directed therapies in RCC are currently listed as recruiting on www.clinicaltrials.gov (last accessed 05/03/18). It should also be noted that these treatments are likely to be used long-term thus exposing patients to enduring toxicity, whereas our study (and others) have shown that effective local treatment can control metastatic sites for a number of years before systemic treatment is needed.

There are several limitations of our study. These include its retrospective nature and inclusion of a relatively small number of patients with heterogeneous disease characteristics in terms of tumour burden and subsequent or previous treatments. We know from surgical series that median overall survival in patients with pancreatic metastases is longer than patients with metastatic disease from RCC elsewhere [39, 40] and $29 \%$ of patients in our study were treated for isolated pancreatic metastases which may have positively influenced our overall outcomes. There is also variability in radiotherapy treatment received in terms of fractionation size and total dosage. Collection of data over a long time course means that changes in both radiotherapy technique and systemic approaches changed over the study period. Nevertheless, we feel that the results of this study provide a valuable insight into the significant potential benefits of high dose radiotherapy in the management of oligometastatic RCC.

This study provides proof of principle that radiotherapy delivered with conventionally fractionated IMRT is effective in achieving long-term control of intraabdominal and retroperitoneal oligometastases. Recent advances in understanding the role of the immune response in RCC may widen the utility of radiotherapy in RCC treatment, as reviewed recently [41]. Decisions regarding treatment modality for oligometastatic RCC should be made in a multi-disciplinary setting. We feel that conventionally fractionated radiotherapy is an under-utilised but extremely useful tool in the management of such patients, especially those in whom surgery and SBRT are not deemed suitable, and its use should be more widely implemented. We hope that this study provides some guidance and acts as a catalyst for future research in this area.

\section{RESEARCH SUPPORT}

SJW is supported by a research scholarship funded by The Urology Foundation.

This study has not been previously presented.

\section{DISCLAIMERS}

IM, ABA, and SJW have no disclaimers. KF has received honoraria for consultancy and advisory board activities from Pfizer, Roche, Novartis, and Bristol Myers Squibb. TE is employed by AstraZeneca and has received honoraria for consultancy and advisory board activities from GSK, Pfizer, Roche, Novartis, and Bristol Myers Squibb.

\section{CONFLICT OF INTEREST STATEMENT}

The authors declare no conflict of interest in respect to the above study.

\section{REFERENCES}

[1] Zerbi A, Ortolano E, Balzano G, Borri A, Beneduce AA, Di Carlo V. Pancreatic metastasis from renal cell carcinoma: Which patients benefit from surgical resection? Ann Surg Oncol. 2008;15(4):1161-8.

[2] Beuselinck B, Oudard S, Rixe O, Wolter P, Blesius A, Ayllon J, Elaidi R, Schöffski P, Barrascout E, Morel A, Escudier B, Lang H, Zucman-Rossi J, Medioni J. Negative impact of bone metastasis on outcome in clear-cell renal cell carcinoma treated with sunitinib. Ann Oncol. 2011;22(4):794-800.

[3] Gravis G, Chanez B, Derosa L, Beuselinck B, Barthelemy P, Laguerre B, Brachet PE, Joly F, Escudier B, Harrison DJ, Laird A, Vasudev N, Ralph C, Larkin J, Lote H, Salem N, Walz J, Thomassin J, Sfumato P, Stewart GD, Boher JM, Renal Cross Channel, Grp (2016) Effect of glandular metastases on overall survival of patients with metastatic clear cell renal cell carcinoma in the antiangiogenic therapy era. Urologic oncology. 2016;34(4):167. e17-167.e23. 
[4] Crispen PL, Breau RH, Allmer C Lohse CM, Cheville JC, Leibovich BC, Blute ML. Lymph node dissection at the time of radical nephrectomy for high-risk clear cell renal cell carcinoma: Indications and recommendations for surgical templates. Eur Urol. 2011;59:18-23.

[5] Thomas AZ, Adibi M, Borregales LD, Hoang LN, Tamboli $\mathrm{P}$, Jonasch E, et al. Surgical management of local retroperitoneal recurrence of renal cell carcinoma after radical nephrectomy. J Urol. 2015;194(2):316-22.

[6] Adamo R, Greaney PJ, Witkiewicz A, Kennedy EP, Yeo CJ. Renal cell carcinoma metastatic to the duodenum: Treatment by classic pancreaticoduodenectomy and review of the literature. J Gastrointest Surg. 2008;12(8): 1465-8.

[7] Ballarin R, Spaggiari M, Cautero N, de Ruvo N, Montalti $\mathrm{R}$, Longo $\mathrm{C}$, et al. Pancreatic metastases from renal cell carcinoma: The state of the art. World Journal of Gastroenterology. 2011;17(43):4747-56.

[8] Law CHL, Wei AC, Hanna SS, Al-Zahrani M, Taylor BR, Greig PD, et al. Pancreatic resection for metastatic renal cell carcinoma: Presentation, treatment, and outcome. Ann Surg Oncol [Internet]. 2003;10(8):922-6.

[9] Sohn T, Yeo CJ, Cameron JL, Nakeeb A, Lillemoe KD. Renal cell carcinoma metastatic to the pancreas:results of surgical management. J Gastrointest surg. 2000;5(4): 346-51.

[10] Chen F, Fujinaga T, Shoji T, Miyahara R, Bando T, Okubo $\mathrm{K}$, et al. Pulmonary resection for metastasis from renal cell carcinoma. Interact Cardiovasc Thorac Surg. 2008;7: 825-8.

[11] Faure JP, Tuech JJ, Richer JP, Pessaux P, Arnaud JP, Carretier M. Pancreatic metastasis of renal cell carcinoma: Presentation, treatment and survival. J Urol. 2001;165(1):20-2.

[12] Akatsu T, Shimazu M, Aiura K, Ito Y, Shinoda M, Kawachi $\mathrm{S}$, et al. Clinicopathological features and surgical outcome of isolated metastasis of renal cell carcinoma. Hepatogastroenterology [Internet]. 2007;54(78):1836-40.

[13] D'Ambra M, Ricci C, Casadei R, Minni F. Pancreatic metastasis from renal cell carcinoma. Urologia. 2011;78(Suppl 1):5-8.

[14] Markinez I, Jimenez R, Ruiz I, Villarreal E, Lizarazu A, Borda N, et al. Pancreatic metastases due to renal carcinoma. Our Cases and a Literature Review. Cir Esp. 2013;91(2): 90-5.

[15] Tanis PJ, van der Gaag NA, Busch OR, van Gulik TM, Gouma DJ. Systematic review of pancreatic surgery for metastatic renal cell carcinoma. Br J Surg. 2009;96(6): 579-92.

[16] Lee Y, Auh SL, Wang Y, Burnette B, Wang Y, Meng Y, et al. Therapeutic effects of ablative radiation on local tumor require CD8 + T cells: Changing strategies for cancer treatment. Blood. 2009;114(3):589-95.

[17] Shu Yan Huo A, Lawson Morris D, King J, Glenn D. Use of percutaneous radiofrequency ablation in pulmonary metastases from renal cell carcinoma. Ann Surg Oncol. 2009;16(11):3169-75.

[18] Duan XH, Li YS, Han XW, Wang YL, Jiao DC, Li $\mathrm{TF}$, et al. C-arm CT-guided renal arterial embolisation followed by radiofrequency ablation for treatment of patients with unresectable renal cell carcinoma. Clin Radiol. 2016;71(1):79-85.

[19] Blanco AI, Teh BS, Amato RJ. Role of radiation therapy in the management of renal cell cancer. Cancers. 2011;3(4):4010-23.
[20] Lwu S, Goetz P, Monsalves E, Aryaee M, Ebinu J, Laperriere $\mathrm{N}$, et al. Stereotactic radiosurgery for the treatment of melanoma and renal cell carcinoma brain metastases. Oncol Rep. 2013;29(2):407-12.

[21] Stinauer MA, Kavanagh BD, Schefter TE, Gonzalez R, Flaig T, Lewis K, et al. Stereotactic body radiation therapy for melanoma and renal cell carcinoma: Impact of single fraction equivalent dose on local control. Radiat Oncol. 2011;6:34.

[22] Singh D, Chen Y, Hare MZ, Usuki KY, Zhang H, Lundquist $\mathrm{T}$, et al. Local control rates with five-fraction stereotactic body radiotherapy for oligometastatic cancer to the lung. $\mathrm{J}$ Thorac Dis. 2014;6(4):369-74.

[23] Ranck MC, Golden DW, Corbin KS, Hasselle MD, Liauw SL, Stadler WM, et al. Stereotactic body radiotherapy for the treatment of oligometastatic renal cell carcinoma. Am J Clin Oncol. 2013;36(6):589-95.

[24] Altoos B, Amini A, Yacoub M, Bourlon MT, Kessler EE, Flaig TW, et al. Local control rates of metastatic renal cell carcinoma (RCC) to thoracic, abdominal, and soft tissue lesions using stereotactic body radiotherapy (SBRT). Radiat Oncol. 2015;10:218.

[25] Wersäll PJ, Blomgren H, Lax I, Kälkner K-M, Linder C, Lundell G, et al. Extracranial stereotactic radiotherapy for primary and metastatic renal cell carcinoma. Radiother Oncol. 2005;77(1):88-95.

[26] Gravis, G., Faure, M., Rybikowski, S., Dermeche, S., Tyran, M., Calderon, et al. Radiation therapy following targeted therapy in oligometastatic renal cell carcinoma. Mol Clin Oncol. 2015;3, 1248-12(3):1248-50.

[27] Cheung P, Thibault I, Bjarnason GA. The emerging roles of stereotactic ablative radiotherapy for metastatic renal cell carcinoma. Curr Opin Support Palliat Care. 2014;8(3): 258-64.

[28] Tanis PJ, van der Gaag N, Busch ORC, van Gulik TM, Gouma DJ. Systematic review of pancreatic surgery for metastatic renal cell carcinoma. Br J Surg. 2009;96(6): 579-92.

[29] Ning S, Trisler K, Wessels BW, Knox SJ. Radiobiologic studies of radioimmunotherapy and external beam radiotherapy in Vitro and in Vivo in human renal cell carcinoma xenografts. Cancer. 1997;80:2519-28.

[30] Fuks Z, Kolesick R. Engaging the vascular component of the tumor response. Cancer Cell. 8(2):89-91.

[31] Dabestani S, Marconi L, Hofmann F, Stewart F, Lam TBL, Canfield SE, et al. Local treatments for metastases of renal cell carcinoma: A systematic review. Lancet Oncol. 2014;15:e549-61.

[32] Kulzer L, Rubner Y, Deloch L, Allgäuer A, Frey B, Fietkau $\mathrm{R}$, et al. Norm- and hypo-fractionated radiotherapy is capable of activating human dendritic cells. J Immunotoxicol. 2014;11(4):328-36.

[33] Filatenkov A, Baker J, Mueller AMS, Kenkel J, Ahn G$\mathrm{O}$, Dutt $\mathrm{S}$, et al. Ablative tumour radiation can change the tumor immune cell microenvironment toinduce durable complete remissions. Clin Cancer Res. 2015;21(16): 3727-39.

[34] Ludgate CM. Optimizing cancer treatments to induce an acute immune response: Radiation abscopal effects, PAMPs, and DAMPs. Clin Cancer Res. 2012;18(17): 4522-5.

[35] Reynders K, Illidge T, Siva S, Chang JY, De Ruysscher D. The abscopal effect of local radiotherapy: Using immunotherapy to make a rare event clinically relevant. Cancer Treat Rev. 2015;41(6):503-10. 
[36] Park SS, Dong H, Liu X, Harrington SM, Krco CJ, Grams M, Mansfield AS, Furutani KM, Olivier KR, Kwon ED. PD-1 restrains radiotherapy-induced abscopal effect. Cancer Immunol Res. 2015;3(6):610-9.

[37] Siva S, Pham D, Kron T, Bressel M, Lam J, Han TH, et al. Stereotactic ablative body radiotherapy for inoperable primary kidney cancer: A prospective clinical trial. BJU Int. 2017;120(5):623-30.

[38] Santoni M, Berardi R, Amantini C, Burattini L, Santini D, Santoni G, Cascino, S. Role of natural and adaptive immunity in renal cell carcinoma response to VEGFR-TKIs and mTOR inhibitor. Int J Cancer. 2014;134(12):2772-7.

[39] Gravis G, Chanez B, Derosa L, Beuselinck B, Barthelemy P, Laguerre B, et al. Effect of glandular metastases on overall survival of patients with metastatic clear cell renal cell carcinoma in the antiangiogenic therapy era. Urol Oncol Semin Orig Investig. 2016;34(4):167.

[40] Grassi P, Verzoni E, Mariani L, De Braud F, Coppa J, Mazzaferro V, et al. Prognostic role of pancreatic metastases from renal cell carcinoma: Results from an Italian center. Clin Genitourin Cancer. 2013;11(4):484-8.

[41] Siva S, Kothari G, Muacevic A, et al. Radiotherapy for renal cell carcinoma: Renaissance of an overlooked approach. Nat Rev Urology. 2017;14:549-63.

[42] DiBiase SJ, Valicenti RK, Schultz D, Xie Y, Gomella LG, Corn BW. Palliative irradiation for focally symptomatic metastatic renal cell carcinoma: Support for dose escalation based on a biological model. J Urol. 1997;158:746-749.

[43] Hoerner-Rieber J, Duma M, Blanck O, Hildebrandt G, Wittig A, Lohaus F, Flentje M, Mantel F, Krempien R, Eble MJ, Kahl KH, Boda-Heggemann J, Rieken S, Guckenberger M. Stereotactic body radiotherapy (SBRT) for pulmonary metastases from renal cell carcinoma-a multicenter analysis of the German working group "Stereotactic Radiotherapy". J Thorac Dis. 2017;9(11):4512-22.

[44] Onufrey V, Mohiuddin M. Radiation therapy in the treatment of metastatic renal cell carcinoma. Int J Radiat Oncol Biol Phys. 1985;11:2007-9.

[45] Svedman C, Sandström P, Pisa P, Blomgren H, Lax I, Kälkner K-M, Nilsson S, Wersäll P. A prospective Phase II trial of using extracranial stereotactic radiotherapy in primary and metastatic renal cell carcinoma. Acta Oncol. 2006;45(7):870-5.

[46] Wang CJ, Christie A, Lin M-H, et al. Safety and efficacy of stereotactic ablative radiation therapy for renal cell carcinoma extracranial metastases. Int J Radiat Oncol Biol Phys. 2017;98(1):91-100.

[47] Zelefsky MJ, Greco C, Motzer R, et al. Tumor control outcomes following hypofractionated and single-dose stereotactic image-guided intensity-modulated radiotherapy for extracranial metastases from renal cell carcinoma. Int J Radiat Oncol Biol Phys. 2012;82(5):1744-8. 